\title{
Of Paradigms and Power British Economic Policy Making since Thatcher
}

\author{
Carstensen, Martin B.; Matthijs, Matthias
}

Document Version

Accepted author manuscript

\section{Published in:}

Governance: An international journal of Policy, Administration, and Institutions

DOI:

10.1111/gove.12301

Publication date:

2018

License

Unspecified

Citation for published version (APA):

Carstensen, M. B., \& Matthijs, M. (2018). Of Paradigms and Power: British Economic Policy Making since Thatcher. Governance: An international journal of Policy, Administration, and Institutions, 31(3), 431-447. https://doi.org/10.1111/gove.12301

Link to publication in CBS Research Portal

\section{General rights}

Copyright and moral rights for the publications made accessible in the public portal are retained by the authors and/or other copyright owners and it is a condition of accessing publications that users recognise and abide by the legal requirements associated with these rights.

Take down policy

If you believe that this document breaches copyright please contact us (research.lib@cbs.dk) providing details, and we will remove access to the work immediately and investigate your claim. 


\section{Of Paradigms and Power: British Economic Policy Mlaking since Thatcher}

\section{Martin B. Garstensen and Matthias Matthijs}

Journal article (Accepted manuscript*)

\section{Please cite this article as:}

Carstensen, M. B., \& Matthijs, M. (2018). Of Paradigms and Power: British Economic Policy Making since Thatcher. Governance: An international journal of Policy, Administration, and Institutions, 313), 431-447. 001: 10.1111/gove.12301

This is the peer reviewed version of the article, which has been published in final form at DOI: https://doi.org/10.1111/gove.12301

This article may be used for non-commercial purposes in accordance with Wiley Terms and Conditions for Self-Archiving

* This version of the article has been accepted for publication and undergone full peer review but has not been through the copyediting, typesetting, pagination and proofreading process, which may lead to differences between this version and the publisher's final version AKA Version of Record. 


\title{
Of Paradigms and Power:
}

\section{British Economic Policy Making since Thatcher ${ }^{\mathrm{i}}$}

\author{
Martin B. Carstensen \\ Copenhagen Business School \\ mbc.dbp@cbs.dk \\ Matthias Matthijs \\ Johns Hopkins University \\ matthijs@jhu.edu
}

Forthcoming in Governance

\begin{abstract}
:
How do ruling policy paradigms persist over time and why do they often undergo significant internal ideational changes? While the impact of Peter Hall's approach to policy paradigms on the study of governance has been immense, there is a burgeoning consensus that a 'Kuhnian' understanding of paradigms makes punctuated equilibrium style shifts the only game in town. While Hall's approach can account for inter-paradigm change with reference to exogenous shocks, it does not allow for significant ideational shifts to occur intra-paradigm. To remedy this, we place ideational power dynamics at the heart of the study of policy paradigms. We demonstrate the general applicability of our approach by examining the evolution of British macroeconomic policymaking since 1990. We show how key policymakers were able to employ their institutional and ideational power to reinterpret and redefine the dominant neoliberal understanding of the economy to match their own specific ideas and policy priorities.
\end{abstract}

Key words: Britain, economic policy, ideas, neoliberalism, paradigms, power.

\section{Introduction}

Both the global financial crisis of 2007-8 and the euro crisis of 2010-12 were the kinds of large systemic shocks many social scientists would expect to lead to a radical departure from the existing neoliberal paradigm to something new. Yet they did not. Neoliberalism, though heavily bruised, adapted to the new situation, and largely endured (Schmidt and Thatcher 2013; Blyth 2013; Baker 2015). In order to better understand why policy paradigms stand the test of time, this paper focuses on the battle of ideas that takes place within rather than between different paradigms. As our 
point of departure, we revisit Peter A. Hall's seminal 1993 contribution to the political economy literature, but argue that paradigms are a lot more flexible than has previously been theorized, and re-emphasize their 'political' rather than 'scientific' nature. Building on recent efforts to disentangle the by now well established argument that 'ideas matter' from more specific claims about how ideas interact with power (Béland et al. 2016), we introduce the concept of ideational power to our sequential approach in order to explain continuity and change within policy paradigms. Finally, we apply our framework to the evolution of British macroeconomic policymaking since Thatcher was forced out of office in 1990.

Despite the success of Hall's pioneering statement in carving out a central explanatory position for ideas in political science, opposition is increasingly being heard from within the ranks of ideational scholarship. Hall (1993) has thus been criticized for overemphasizing punctuated equilibrium-style change (Blyth 2002; Béland 2007; Carstensen 2011a; Matthijs 2011; Wilder and Howlett 2014), conceptualizing ideas as too static and monolithic, and downplaying the role of agency in processes of ideational change (Widmaier et al. 2007; Berman 2013; Wood 2015), by suggesting that actors effectively internalize the policy paradigm they adhere to (Schmidt 2008; Carstensen 2011b). To contribute to a fruitful new agenda for research on policy paradigms, we suggest in this paper that the dynamics of ideational power take up a central position in accounts of paradigmatic stability and change. Drawing on the earlier work of Matthijs (2011) and more recent work by Carstensen and Schmidt (2016), we suggest that crisis narration, authority contests, and ideational power play a much more central role than exogenous shocks, often leading to gradual ideational change within a paradigm rather than a wholesale paradigm shift as theorized by Hall (1993).

Our enhanced analytical perspective on policy paradigms also translates into a more nuanced analysis of macroeconomic policymaking in postwar Britain - the case that Hall (1993) applied his own policy paradigm framework to - by showing its gradual evolution from Major to Cameron. We argue that through the use of ideational power, successive British Prime Ministers and their Chancellors were able to reinterpret and redefine the dominant neoliberal paradigm to match the macroeconomic context, as well as their own specific ideas and policy priorities. While Tony Blair and Gordon Brown wanted to use a growing state apparatus in order to improve health and education following a variant of post-neoclassical 
endogenous growth theory, David Cameron and George Osborne set out to shrink the state with the aim of bringing down debt levels in order to reinvigorate business and consumer confidence, subscribing to a view of expansionary fiscal austerity. Both significantly different 'varieties of neoliberalism' proved to be largely compatible with the pre-existing Thatcherite paradigm. Indeed, some may argue that they ended up strengthening it.

\section{Taking Stock of Hall's Paradigm Approach}

The work of Peter A. Hall (1993) on the role of policy paradigms in public policy was both path breaking and agenda setting in the field of political economy. Hall's key analytical innovation was to transpose Thomas Kuhn's (1970) theory of scientific revolutions into a theory of public policymaking, which proved useful for the attempt to develop an institutionalist understanding of the role of ideas in politics. Hall (1993) applied three key parts of Kuhn's framework to his analysis of the role of paradigms in policy development: (1) the incommensurability thesis, (2) the importance of anomalies, and (3) the division between 'normal science' and 'paradigm shifts.'

First, with the basic argument that policy paradigms are incommensurable given that "each paradigm contains its own account of how the world facing policymakers operates" (Hall, 1993, p. 280) - Hall took a relatively strong position on both the internal purity of a paradigm and the mutual exclusivity of paradigms. Paradigms were therefore presented as internally coherent, composed of logically connected elements that originated in fundamentally different theories of how an economy works and should work. On both counts, this approach has been subject to criticism. In their re-evaluation of Hall's (1993) case of British macroeconomic policymaking, Oliver and Pemberton (2004) show that rather than exhibiting incommensurability, the paradigm shifts that occurred were less than wholesale, with new ideas being gradually incorporated into the prevailing policy paradigm. By implication, paradigm replacement therefore need not be as absolute as proposed by Hall (1993).

The second Kuhnian element in Hall's paradigm approach subject to critique is the central role of policy anomalies in provoking processes of paradigm shifts. Thus, Hall (1993) argued that, as the supporters of a paradigm encounter developments that contradict the basic tenets of the paradigm - i.e. a building up of anomalies - ad hoc attempts would be made to stretch the terms of the paradigm. 
Over time, this process is likely to slowly eat away at the authority of policymakers and experts who adhere to the failing paradigm, paving the way for a shift towards a new (or old) and competing paradigm. As pointed out by Mark Blyth, this argument in essence tries to juggle two competing ontologies. On one hand, what Blyth (2013) calls 'Bayesian social learning' - taking place in instances of both 'first order' (i.e. policy settings) and 'second order' (i.e. policy instruments) change - that views ideational change as occurring following information updates and experiments. On the other hand, a 'constructivist' approach that understands information updates and experiments as fundamentally in need of interpretation, i.e. as a process that can never be objective or unmediated and remains fundamentally structured by contests over authority and power that will determine 'third order' (i.e. policy paradigm) change. Although Blyth posits that this tension only reveals itself in the empirical part of Hall's paper, in our view the question of how anomalies play into the competition for the authority over a paradigm remains largely open.

Third and finally, the larger issue at stake underlying the question of the incommensurability of paradigms and the role of policy anomalies is how to conceive of dynamics of paradigm change. By distinguishing between two options of change 'normal policymaking' and paradigm shifts - Hall (1993) employed a hard version of the Kuhnian (1970) take on paradigm shifts. The approach allows for only two forms of change: incremental shifts in either policy settings or policy instruments of the paradigm - which in Hall's (1993) original version does not entail change in the ideas that structure the paradigm, and therefore does not amount to significant transformation - and a wholesale shift in the goals and discourse that structure policymaking through the introduction of a rival policy paradigm. In effect, Hall (1993) adopted a 'punctuated equilibrium' model of change based on an assumption about the incommensurability of policy paradigms and the inability or unwillingness of actors to incorporate elements from other paradigms. Recent scholarship has objected that such a model is ill suited to capture the more subtle but no less significant ideational changes that may over time take place within a policy paradigm, instead opting for a model of 'punctuated evolution' (Matthijs 2011; Carstensen 2011a; Hay 2011a; Wilder and Howlett 2014; Wilder 2015).

\section{Intra-Paradigm Ideational Change}


Although it is clear that the authority of a policy paradigm is based to a significant extent on its ability to provide a clear-eyed diagnosis of current developments in the economy, and a way forward in terms of steering it in a more productive direction, we start from the observation that the authority of a paradigm does not rest on its coherence or parsimony, but rather on the overall perception of the paradigm as coherent, parsimonious and able to solve the problems policymakers currently face (Matthijs 2011; Wood 2015). Furthermore, the degree to which this perception is shared in policymaking circles, and supported by societal elites and large parts of the electorate will weigh upon the ability of actors to form coalitions that may support the continuing institutionalization of the policy paradigm (Baumgartner 2013: 251; Blyth 2002; Culpepper 2008; Matthijs 2011).

We therefore follow recent theorizing on paradigms as more composite, flexible and historically specific (e.g. Ban 2016; Wilder 2015; Béland and Cox 2016), which opens the possibility that new ideational elements may be affixed to the existing paradigm, or that certain existing ideational elements within the paradigm are given relatively more or less prominence in actual policymaking. That is, whereas Kuhn's (1970) scientific paradigms are canonized in textbooks and articulated through decades or centuries of scientific practice, policy paradigms have to exhibit greater flexibility and malleability in the face of constantly shifting political contexts (Schmidt and Thatcher 2013).

In Hall's (1993) approach, real ideational change only occurs as one paradigm replaces the existing one, a process crucially enabled by a change in institutional power brought about through a change in actual governing power. Although a range of different actors makes up the coalition that prepares the ground for the paradigm shift, since the new paradigm is institutionalized following a change in government power, the newly elected government is the primary agent of change (see figure 1). Hall's (1993) approach however does little in way of theorizing how ideas may change even though the paradigm does not go through a wholesale shift from old to new. Arguably, a full-blown paradigm shift brought about by a shift in governing power is a relatively rare occurrence - an outlier - and there are therefore very good reasons to consider alternative processes of ideational change within a paradigm. 


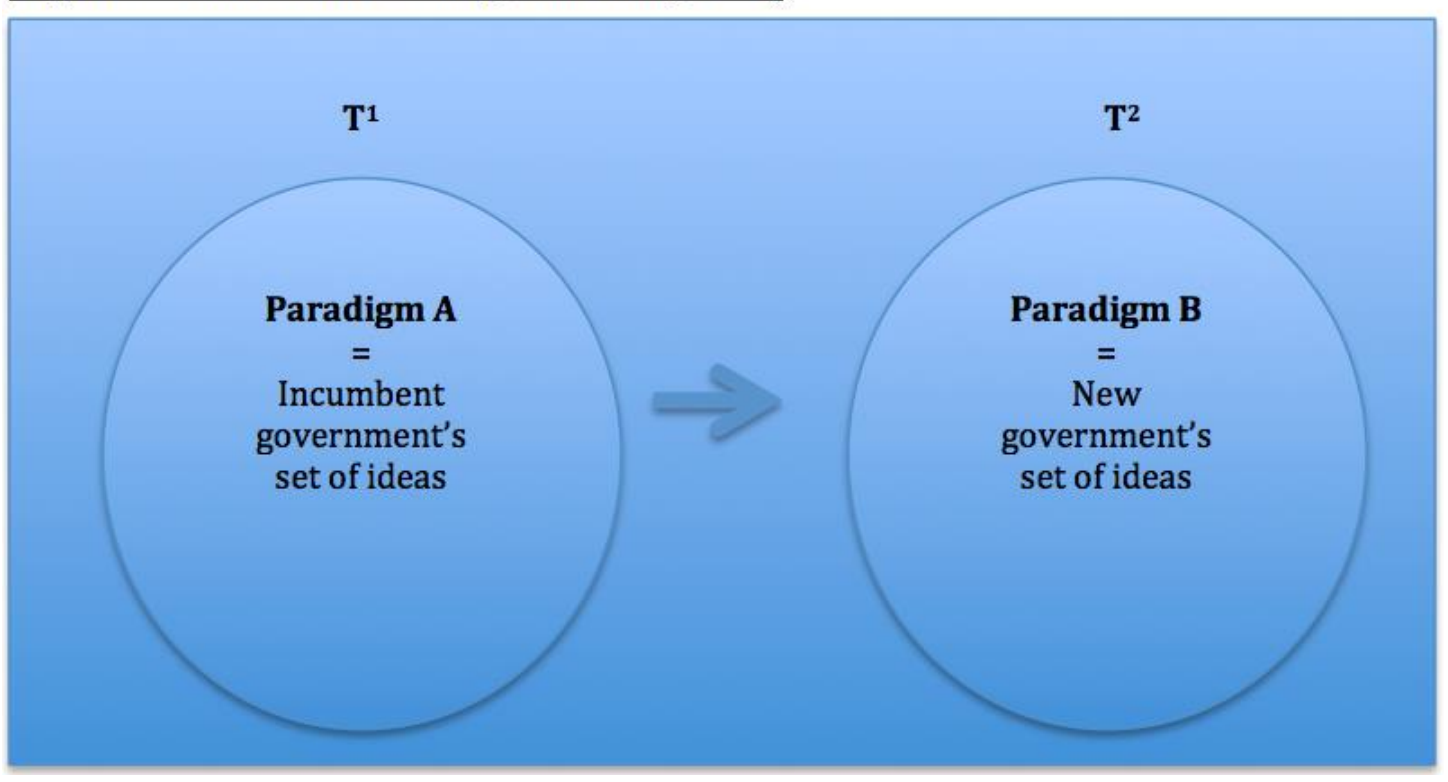

At any one time, a number of ideas are available for policymakers to consider. Naturally, given that ideas have different power-distributional implications (Blyth 2002), and that there are strict limits to the amounts of issues that a political system can deal with at any one time (Baumgartner and Jones 2009), only very few of these ideas actually receive a hearing. Most ideas hence often live a quiet life in relative obscurity, in what Kingdon (2003) called the "primeval soup of ideas." Among the more 'privileged' ideas, we find the ones that make up a policy paradigm. Functioning as the basis of policymaking in one or multiple policy areas, they help policymakers identify problems and solutions, and work as a collective lens through which a government - along with other parties, societal elites, and likely also the electorate at large - deal with issues deemed of importance. But how can ideas change within a paradigm?

To simplify things, imagine economic policymaking within a political system where two parties seek government power, and where they largely do so based on their respective sets of ideas. Consider further that policymaking in the area of macroeconomic policy is guided by a certain paradigm that was first brought to prominence and then institutionalized by the incumbent government (or further back in time). The existing paradigm now generally serves as 'common knowledge' and the taken-for-granted standard operating procedures for macroeconomic policy (Culpepper 2008). A shift towards a different paradigm would require a dramatic loss of authority on part of the existing paradigm, and a clear alternative paradigm to be 
available that is promoted by a powerful alliance of elite actors, including political parties in opposition with the power to institutionalize the alternative paradigm once elected (Hall 1993).

However, in our imagined case, while there is an actual change in governing power, the incoming government party may not seek to change the paradigm. In fact, the set of ideas that frame the policy priorities of the new government is based on the existing paradigm in the sense that it subscribes to similar overall policy goals (e.g. pursuing price stability rather than fighting unemployment), although it differs substantially from the outgoing government in the weight it assigns to the ideas that make up the paradigm. In this case, if the incoming government is able to (1) change the common perception among policymakers (in the party, opposition, among civil servants, public debate, etc.) to accept the changed focus of the policy paradigm, and (2) effect this re-prioritization in actual policymaking, we will have witnessed a shift in the relative weight of the ideational elements within the paradigm. This is illustrated in figure 2.

Figure 2: Gradual change: A Shift in Relative Weight of Ideas within the Paradigm

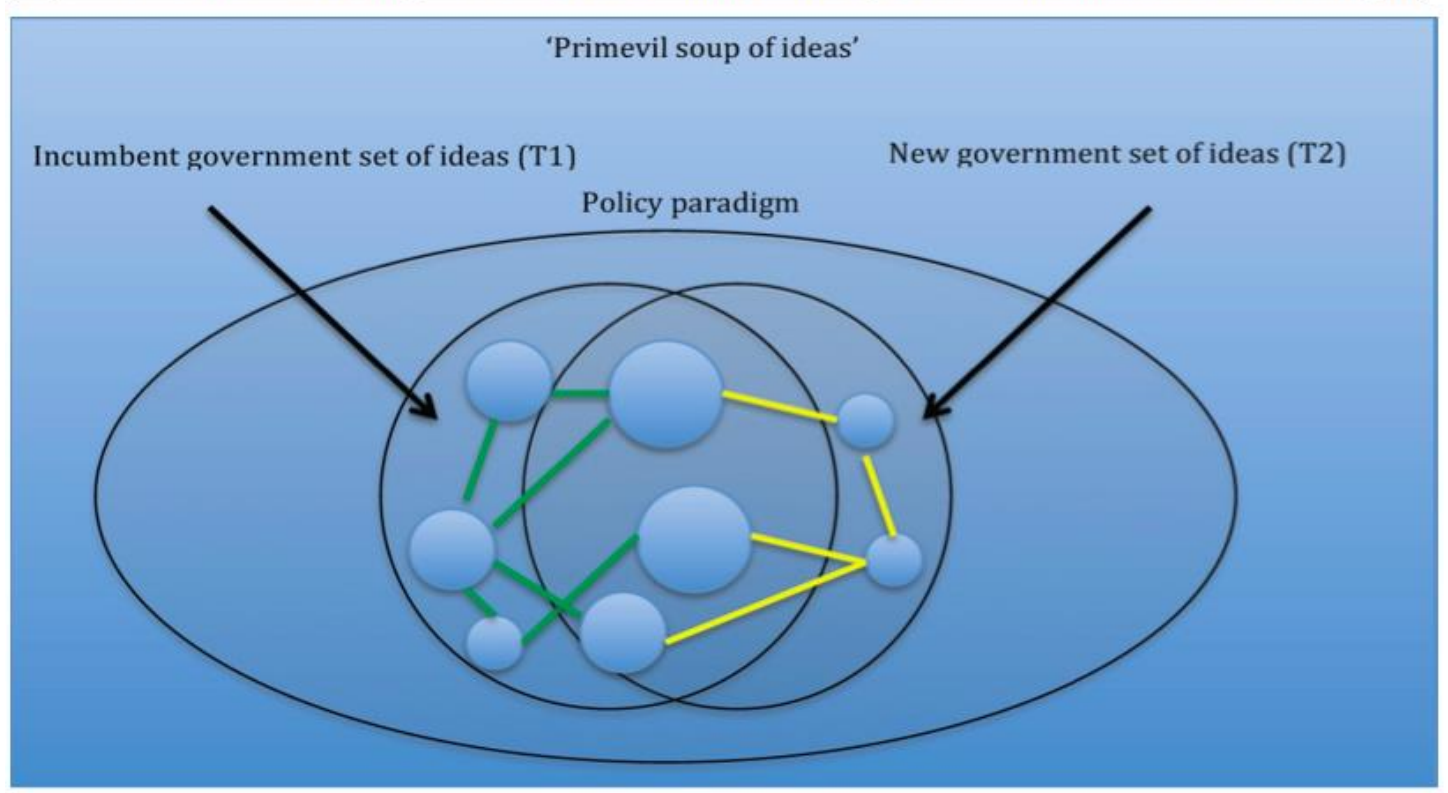

Given that the two sets of ideas are both within the scope of the existing policy paradigm, the degree of change effected as a result of change in government power is limited rather than radical, since it does not entail a shift in the goals that guide policy. However, it may have profound consequences for the government's evolving 
policy agenda. It will also determine the parameters for its potential successor down the line, especially if the intra-paradigm ideational shift proves to be successful in terms of actual outcomes.

Now consider a different scenario, where the two parties share ideas about the fundamental goals of policy, like maintaining price stability and low levels of sovereign debt - and thus both support the basic tenets of the paradigm - but also support ideas that are not currently in the paradigm (see figure 3 ). There is thus a gap between the ideas that each party supports and what is currently included in the paradigm (called the 'ideational gap' in figure 3). The ideas that actors seek to include in the existing policy paradigm may originate in a contending paradigm (as in Europe's short-lived Keynesian turn of 2008-9, or the inclusion of ideas of macroprudential regulation into post-crisis financial framework, see Baker 2015). Alternatively, the new ideas may not belong to any particular paradigm but may have caught the attention of elite actors in power.

\section{Figure 3: Ideational Gap between Paradigm and Government/Opposition Set of Ideas}

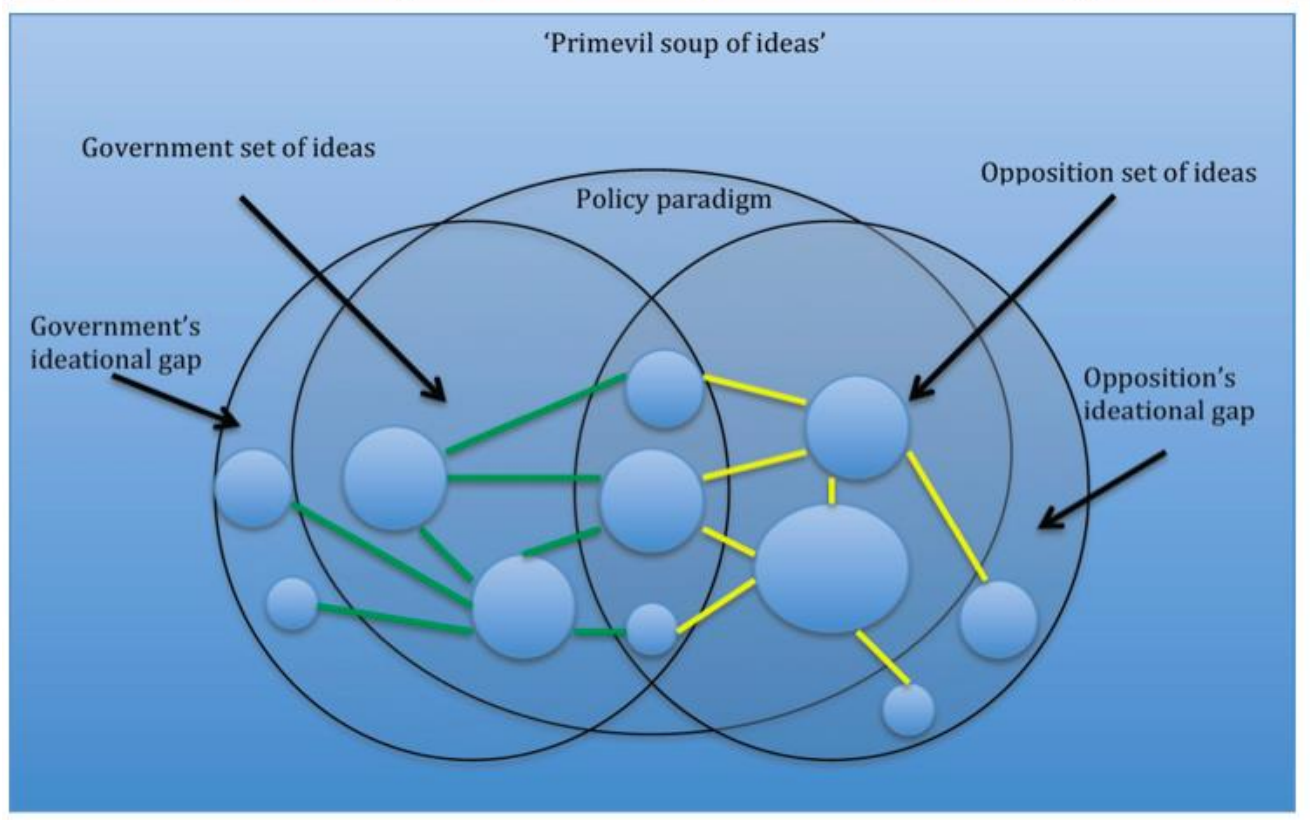

This obviously presents both parties with a challenge, namely to somehow move their ideas from the 'ideational gap' into the existing policy paradigm. This is no mean feat for any of the parties, but since we are here imagining a two-party majoritarian system, whoever holds government power, and thus enjoys most institutional power, clearly stands the better chance to do so. That being said, the battle of ideas is a 
dynamic one, where ideational power not rarely trumps institutional power (Carstensen and Schmidt 2016), and thus the government will have to work actively to be successful in the longer term. Thinking of a policy paradigm in these terms offers a view of how intra-paradigm change may occur, but it leaves open the question not only which factors help stabilize the paradigm, and potentially keeps new ideas from becoming part of it, but also how agents can move their idea from the ideational gap into the established paradigm.

\section{Ideational Power, Policy Paradigms, and Political Change}

Before we move into the thick of the discussion of how ideational power matters for intra-paradigm change, it is important to specify what we mean by 'ideational power.' A key outcome of the classic power debate of the 1960s and 1970s was a recognition that ideas are important for building and sustaining power, whether in decisionmaking processes (Dahl 1957), agenda setting (Bachrach and Baratz 1962) or preference shaping (Lukes 1974). However, despite significant advances in our understanding of power as a multi-dimensional concept, the power debate left the processes through which ideational power impact policymaking largely undertheorized. The ideational turn in the 1990s did much to re-establish the centrality of ideas in politics (Campbell 1998), but most of the energy was put into supporting and developing the foundational claim that 'ideas matter,' while the relation between the different dimensions of power and ideas remained murky. This paper follows on the back of more recent efforts within ideational scholarship to elucidate the ways in which power and ideas interact (Béland et al. 2016).

We take as our point of departure Carstensen and Schmidt's (2016) definition of ideational power as the capacity of actors (whether individual or collective) to influence other actors' normative and cognitive beliefs through the use of ideational elements. This may occur directly in interaction through persuasion or imposition, or indirectly by influencing the ideational context that defines the range of acceptable policy options. From this perspective, acts of ideational power - whether successful or not - only occur in a subset of the relations relevant for understanding how ideas matter, namely when actors seek to influence the beliefs of others by promoting their own ideas at the expense of others.

In this view, ideational power is not a resource that actors somehow possess or may draw upon in their direct or indirect interaction with others. Such a 
conceptualization would obscure how ideational power, like other forms of power, is exercised through the social relations actors are part of in policymaking processes. In the context of ideational power, such social relations concern the constitution of actors (Barnett and Duvall 2005), i.e. in actors having an impact on how other actors inter-subjectively conceive of their interests and preferences (Blyth 2002, Culpepper 2008). What then on a conceptual level sets ideational power apart from other dimensions of power, are the means through which effects are sought to be achieved. These include the use of ideational elements like discourse, framing, theories, etc. (Schmidt 2008) as well as the aims of exerting ideational power, for example by changing the worldview of other actors.

It is worth emphasizing that ideational power rarely is exercised in this pure, ideal-typical form. As is the case for the other dimensions of power, ideational power is typically produced in tandem with other forms of power, making it an important analytical challenge to parse out the most relevant explanatory logics in the case under scrutiny (Parsons 2007). Thus, the actor orientation of the approach outlined in this paper should not be taken to indicate that we somehow disregard other forms of power, like institutional or structural power. To the contrary, and as argued below, successful acts of ideational power are often related to the wielding of other forms of power.

To shed light on how ideational power plays into processes of intra-paradigm change, we suggest a sequential approach based on three types of mutually reinforcing 'ideational powers' as holding the key to making sense of authority contests over how policy paradigms evolve over time. First, ideational power manifests itself under the guise of constraining power of ideas. This refers to the popular authority certain existing ideas enjoy in structuring thought at the expense of other ideas (Carstensen and Schmidt 2016). If we return to our situation of two parties in competition over government power, each seeking to close the gap between the reigning paradigm and their preferred set of ideas, the constraining power of ideas presents them with the challenge that the existing paradigm enjoys authority among elites and holds broad sway over the electoral majority, which in turn puts limits on the degree of ideational change that can be achieved.

The constraining power of ideas works through background ideational processes - constituted by systems of knowledge, rhetorical power, discursive practices and institutional setups - that affect which ideas enjoy authority at the 
expense of other ideas that may have been largely discredited or gone out of fashion. One may think about this kind of authority of ideas in terms of the strength of public philosophies (Schmidt, 2008), public sentiments (Campbell, 1998), or national economic traditions such as ordoliberalism in Germany (Matthijs 2016) that form the background of policymaking processes. However, once policymakers come to accept the existing paradigm - either out of political necessity or ideological conviction - the constraining power of ideas may also work as a resource. This means that they can function as the deeper-level ideational structures that actors draw upon and relate their ideas to in order for them to gain recognition among both elites as well as the mass public (Boswell and Hampshire 2017).

Second, persuasive power through ideas refers to the epistemic capacity of actors to convince other actors to accept and adopt their views of what to think and do through the use of ideational elements (Carstensen and Schmidt 2016). Rather than viewing power as making someone do what they would otherwise not have done by force, threats, institutional position, or material resources, the ideational power actors exercise is based on their capacity to induce other actors to do something through reasoning or argument. This form of power relates both to the efforts of elites to convince one another about the 'appropriateness' of certain programmatic ideas, as well as the communication that goes on between elite and the mass population, or "communicative discourse" (Schmidt 2008). Equally, if actors are seeking to promote the rise of a new paradigm, this requires an actual perception of crisis in the existing paradigm, which turns on the ability of actors to develop and communicate a convincing crisis narrative that explains what went wrong and how the problem can be solved (Blyth 2002; Matthijs 2011).

In terms of our sequential approach of intra-paradigm ideational change, the persuasive power through ideas typically comes into play as governments seek to either shift the relative weight of ideas within the paradigm or move adjacent ideas into the policy paradigm. This could be done during 'normal' times, by justifying a growing state sector to correct for market failures or by reframing public 'spending' as 'investment' (see e.g. Jenson 2010). During periods of crisis, 'saving the economy' may require either a short-term boost in demand or longer-term supply-side measures. Which measures end up being enacted will depend on whether the crisis is constructed as a crisis of 'too little growth' or one of 'too much debt.' We may likewise imagine that proponents of the reigning paradigm are able to attach a new 
idea to the paradigm by constructing it as a necessary answer to growing anomalies, as Gordon Brown's Labour did in the early 2000s to use state action to increase productivity, or George Osborne's Tories, who increased the powers of the Bank of England to better regulate the country's banking sector after the financial crisis.

Third, and finally, institutional power over ideas refers to the capacity of actors to define and rule over the meaning of the body of ideas that constitute a paradigm. Although the persuasive power of ideas is key in establishing support around a new narrative for the economy that advantages certain parts of the policy paradigm at the cost of other ideas, to bring a broader institutionalization of the ideational shift to fruition requires the effective use of institutional power over ideas. This form of power may take multiple shapes, but it usually involves actors deploying both ideational and institutional power to ensure that their ideas remain predominant so as to guard against direct or future challenges to their exercise of coercive power, or questioning of their structural and institutional powers.

In the case of policy paradigms, the most relevant deployment of institutional power over ideas comes in the form of the ability of actors not to listen, i.e. a capacity to resist or veto alternative ideas (Matthijs and McNamara 2015). What often characterizes such policy actors, clustered in closed groups of people - as a part of, for example, epistemic communities, discourse coalitions, interest groups, or advocacy networks - is that they are able to harness enough legitimacy around their policy ideas to avoid considering alternative approaches. As mentioned, such power connects with the more standard understanding of institutional power that comes with taking over the reins of government - e.g. to place actors supportive of the government's agenda centrally in government institutions - or reshuffling policy areas and budgets to advantage the government institutions that are particularly important for bridging the ideational gap between existing paradigm and the vision of the new government.

Institutional power over ideas also matters for when anomalies in a paradigm set off processes of significant change. What is important is how and when policy actors are able to successfully frame instances that threaten the authority of the paradigm as actual anomalies. Succinctly put, given that paradigms are fundamentally political in nature, they cannot be proved wrong (Blyth 2013). To this end, Wilder and Howlett (2014: 194) employ the term 'gatekeeper' to designate the policy actors that adapt evidence, either positively or negatively, to conform to political preferences, 
and amend existing solution sets or complement cognitive schemas. Such gatekeepers enjoy significant 'institutional power over ideas' in that they may frame what may be considered an anomaly (e.g. banks being 'too big to fail') as possible to handle within the existing paradigm (e.g. regulation on 'systemic risk,' 'living wills,' or the need for a banking union in euro governance). In sum, the short-term changes that are possible to effect with the use of ideational power through persuasion require institutional power over ideas to ensure the long-term resilience of gradual shifts in the composition of the paradigm.

As we will see next, there were several important changes in British economic policymaking after 1990 that can be explained by employing our sequential approach to ideational power. This includes John Major's enthusiasm for industrial policy, Blair's dramatic increase in the size of the state to invest in health and education in an effort to increase productivity, Brown's Keynesian turn, and Cameron's embrace of austerity. All four felt the constraining power of the neoliberal paradigm going into office and did not question the overall goal of economic policymaking. But all four used their powers of persuasion to make space within that existing paradigm to change both the role as well as the size of the state in the economy. Actually bringing about that intra-paradigm change of ideas required the use of their institutional power over ideas, which they could only effectively employ once they were in power.

\section{"Varieties of Neoliberalism:" Ideational Power in British Economic Policymaking}

Since Margaret Thatcher swept to power in 1979, the neoliberal paradigm has reigned supreme over UK economic policymaking. We define "neoliberalism" as the economic policy paradigm that subscribes to the fundamental principle that markets (not states) are the main engine for economic growth, while governments' macroeconomic policy should prioritize price stability over full employment, refrain from actively managing the business cycle, and only intervene on the supply side to correct market failures. Neoliberals believe that a high level of employment is achieved through microeconomic policies, such as labor market deregulation, while faster growth stemmed from supply-side policies aimed to increase the long-term potential of the economy, including privatizing state owned enterprises, product market deregulation, financial market liberalization, and free trade (Matthijs 2011, p. 122). Over the course of the 1980 s, the UK economy saw plenty of learning and 
experimenting with various policy 'settings' (targeting the money supply, interest rates, or the exchange rate) and different policy 'instruments' (monetary, fiscal, trade, and labor market policy), but the neoliberal paradigm was always guiding the overall policy framework (Hall 1993).

However, while the policies of the three Thatcher governments from 1979 to 1990 were remarkably consistent in their policy approach, subsequent governments led by Major, Blair, Brown, and Cameron - would all use their ideational power to mold the neoliberal paradigm to their own image and beliefs. While the main goal of British macroeconomic policy, i.e. price stability, was never questioned, their ideas as to the role of the state in the economy as well as the overall size of the state (as shown in figure 4) would be significantly different. ${ }^{\text {ii }}$ This ideational change did not manifest itself purely on the level of Hall's 'settings' or 'instruments,' but somewhere between those two levels and the level of the actual 'goals' of the paradigm. We refer to them as the 'secondary' goals - after price stability was achieved or taken for granted - of what the foundations of the British economy should be, what kind of society the British people want, and which actual policy outcomes should be prioritized.

\section{Figure 4: UK Government Expenditures and Revenues (\% of GDP)}

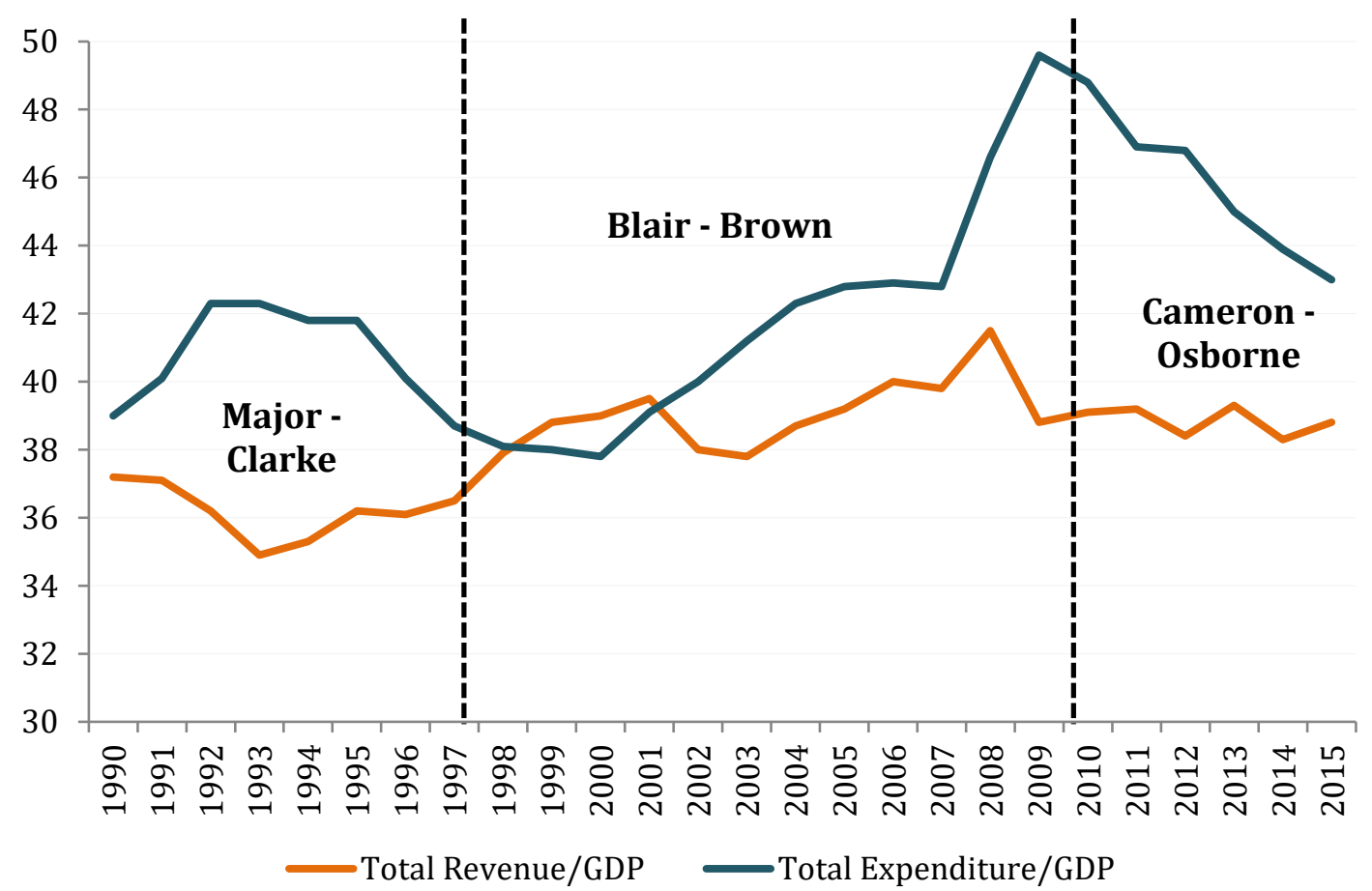

Source: European Commission (2016), Ameco Database. 
The size of the state in Britain's economy (figure 4), as measured in total expenditure as a percentage of GDP, varied substantially over time. While Major kept the size of the state at roughly 39 percent (expenditures went up to 42 percent after the recession of 1990-92, but were brought down again), Blair and Brown increased the size of the state during the boom to reach 46.6 percent in 2008, culminating in a post-global financial crisis high of 49.6 percent in 2009 (compared to a post-recessionary peak of 42.3 percent in 1992). Cameron and Osborne set out on a path of fiscal austerity, which would reduce the size of the British state from 48.8 percent in 2010 to 43 percent in 2015, with a Conservative manifesto goal to reduce it to just 38 percent by 2020. We will show that ideational power would not just affect the size but also the role of the state in the British economy.

\section{Intra-Paradigm Ideational Change from Major to Blair and Brown (1990-2007)}

\section{Thatcherism with a Human Face (1990-1997)}

The Conservative Party's 1992 general election victory on the back of a steep recession proved to be crucial for the evolution of economic policymaking in Britain. With 41.9 percent of the vote, Major's Tories were reelected with an absolute though much diminished majority. They would set out to complete the Thatcher revolution with further privatizations and continued deregulation. After the Black Wednesday debacle in September 1992, which saw sterling forced out of the European Exchange Rate Mechanism (ERM), the British economy began its longest sustained period of growth ever. Low interest rates spurred investment, a weaker pound fueled exports, and newly appointed Chancellor Kenneth Clarke's policy of tight spending control brought back business confidence. This led to five years of economic growth between 1992 and 1997, with the fruits of the new income spreading more widely as the steep rise in income inequality came to a halt in the 1990s.

With Michael Heseltine at the Department of Trade and Industry, and later as Deputy Prime Minister, the Conservative government even started to move away from its rhetoric of raw free market capitalism, by bringing back the possibility of a more activist industrial policy to help reverse the decline in manufacturing. Heseltine made ideational space within the existing paradigm for more active government intervention, promising to "intervene before breakfast, lunch, and tea" with a relentless focus on UK global competitiveness. Rather than picking winners, the many 
White Papers that were commissioned under Heseltine focused on correcting market failures, including for example to reap the positive externalities and spillovers from public investment in R\&D.

But as Major's Tories were making space within the paradigm for new ideas, the Labour Party fully embraced a Thatcherite version of neoliberalism after Blair became its leader in 1994, and Brown was given veto power over economic policy. In their 1997 election manifesto, though 'New' Labour promised to pursue a 'third way' policy "that differs from the old left and the Conservative right," in effect they accepted the neoliberal paradigm. ${ }^{\text {iii }}$ Brown promised to pursue price stability as his main goal, and pledged not to veer away from Clarke's tax and spend policies for the first two years in office. Blair and Brown were convinced that four consecutive electoral defeats at the hands of the Tories was because of the old left's loss of control over the economic narrative, which was no longer persuasive to either policy elites or the general public.

By accepting the constraining power of the Tories' ideas on macroeconomic policy, they in effect fought the last war, as already by 1995 it was obvious that New Labour would have been elected no matter what. They initially felt compelled to sacrifice most of their social democratic goals at the neoliberal altar, underscoring the Tories' persuasive and institutional power over ideas. Major's Tories had already slowly moved towards more activist government intervention, and no longer took a dogmatic view of the virtues of a minimal state and privatization as the cure for all the government's ills.

\section{Prudence for a Purpose and the Third Way (1997-2007)}

Once New Labour was in power, they would further cement the neoliberal consensus, even though the Treasury's moves were justified as 'prudence for a purpose' (Keegan 2004, our emphasis). A mere five days into office, Chancellor of the Exchequer Gordon Brown took the financial world by surprise by announcing the formal independence of the Bank of England (BoE). While this was hailed at the time as a stroke of genius, what it did was institutionalize low inflation as the primary goal of monetary policy. The BoE would define price stability as within a one-percent symmetrical band of a 2 percent target. Brown also kept his promise to continue with the Tories' fiscal spending plans, creating what he called a "platform of stability" (Matthijs 2011, p. 165). He introduced a "golden rule" which committed the 
government to only borrow to invest (rather than fund current expenditure) and to maintain a budgetary balance over the business cycle. This resulted in budget surpluses in 1999, 2000, and 2001, allowing Labour to pay down the national debt, and reduce the debt-to-GDP ratio from 48.7 percent in 1997 to 37.1 percent by 2002 (Eurostat 2016). Until Blair's reelection in 2001, there was very little ideational change from the Major years from a macroeconomic point of view. ${ }^{\text {iv }}$ By 2001, the Labour government "was actually managing to spend less on core public services as a percentage of GDP than the much derided government of John Major" (Gamble 2005, p. 435).

Gradual ideational change would come in Blair's second term as the whole idea of the 'Third Way' would prove itself to be less vapid than many critics believed at the time (Hay 1999; Heffernan 2001). Often dismissed as a cynical electoral strategy of 'triangulation' and a clever tacking towards the center, or a new politics to bring government closer to the people, Third Way thinking was given shape as a policy agenda. The Third Way combined economic efficiency with social justice during Blair's second and third terms, and was given more coherence over time. Brown's main objective was to fight for social justice and against widening income inequality by pushing British welfare standards closer towards the levels of provision enjoyed by the citizens in continental Europe (Gamble 2005). Back in the 1990s, prodded by his closest economic adviser Ed Balls, Brown got his inspiration from new developments in institutional economics, especially from endogenous growth theory, which allowed an important role for government to achieve a highly productive labor force by sustaining investment in areas such as health, education, infrastructure, and research and development (Clift and Tomlinson 2007, p. 62-66; Matthijs 2011, p. 159). The endogenous growth literature was situated within the neoclassical economic tradition, far away from any neo-Keynesian or Marxist influences.

In a direct challenge to the neoliberal paradigm on tax and spend, however, Blair and Brown set out to expand the size of government during the 2002 spending review, by announcing an annual increase of 8.6 percent in health and 5.2 percent in education, to be paid for by a hike in national insurance contributions. While Blair and Brown had been very reluctant back in 1997 to raise taxes, by 2002 they had come to believe that the British people were willing to pay more in taxes as long as they could see where the money was going (Seldon 2005, p. 418). Figure 5 illustrates 
how health spending steadily rose during Labour's time in office, from a measly 5.4 percent of GDP in 2000 to a high of 8 percent of GDP in 2009, with public spending on education increasing from a low point of 4.4 percent of GDP in 1998 to 6.6 percent of GDP in 2009.

Brown proved himself to be a much more 'activist' chancellor than Ken Clarke, constantly tinkering with the tax code to improve social indicators and standards of living for workers. One indicator of this change is the reversal of labor's overall compensation as a percentage of total income after it came to power. Labor's share of national income peaked in Britain in 1975 at 63.4 percent of GDP, and steadily fell to an all-time low of 48.5 percent in 1996. By 2009, it was back at 53.5 percent (Ameco 2016). Neoliberalism had not been replaced under Labour by a new paradigm, but it had morphed into something very different from the Thatcher or Major years. In effect, Brown had managed to bridge the ideational gap with the Tories by bringing in social democratic elements into a broadening neoliberal tent. Showing the powerful appeal of Labour's narrative across political elites, especially its persuasive power through ideas, the Tories matched Labour's generous spending targets during the 2005 elections, just like New Labour had matched the Conservatives' austere fiscal plans in 1997. ${ }^{v}$ But the voters carried Labour back into office in 2005 despite the Iraq war fiasco of 2003, underlining the new mass appeal of Labour's ideas. In June 2007, Blair would give way to Brown. 
Figure 5: UK Government Expenditure on Health \& Education (\% of GDP) ('97-'14)

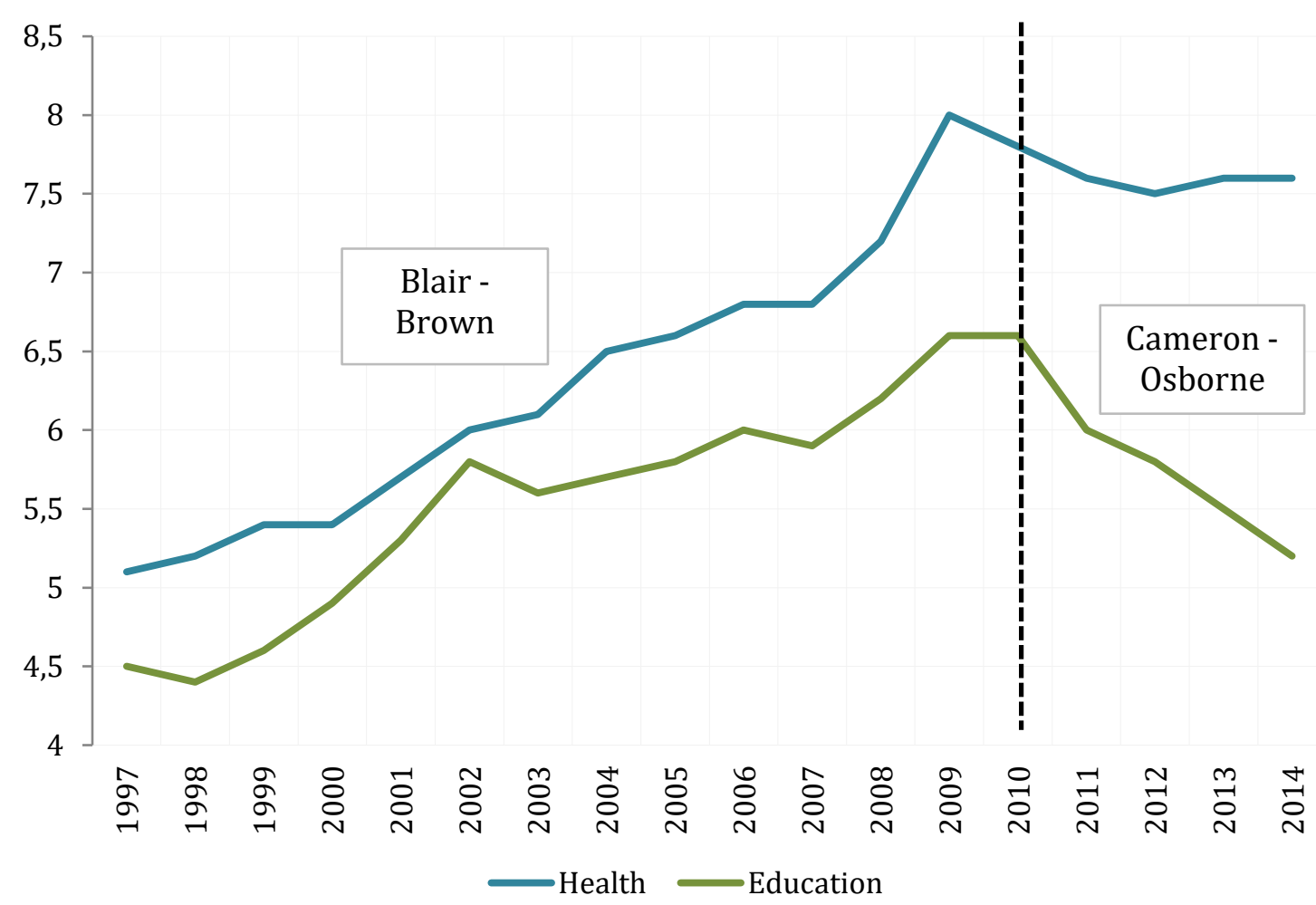

Source: Eurostat (2016)

Ideational Change from Brown to Cameron and Osborne (2007-2016)

Brown's Inter-Paradigm Borrowing: The Brief Return of Keynes (2007-2010)

The advent of the global financial crisis saw swift action on the part of Prime Minister Brown and his Chancellor Alistair Darling. In October 2008, they announced a rescue package for the country's banking sector amounting to a whopping 28 percent of GDP. The BoE cut interest rates from 3 percent in November 2008 to 0.5 percent by February 2009, the lowest rate in the Bank's existence. A large fiscal stimulus ensued, including a $£ 2.3$ billion package to rescue the ailing automotive industry, as the BoE moved from rate cuts to consecutive rounds of quantitative easing. In a further move away from the neoliberal paradigm, Darling announced an income tax increase for incomes higher than $£ 150,000$ from 40 to 50 percent, as well as an additional 'supertax' on bankers' bonuses above $£ 250,000$ (Matthijs 2011, p. 194). The latter was a far cry from Labour's earnest commitment in 1997 that there would be "no increase in the basic or top rates of income tax." (Labour Party 1997). 
But rather than using the global financial crisis as evidence of the culmination of a long building up of anomalies within the neoliberal paradigm, Brown's temporary turn to Keynesian tools amounted to a brief spell of what Colin Hay has called "inter-paradigm borrowing," used to rehabilitate the existing growth model (Hay 2011b, p. 253). In effect, Brown and Darling managed to stabilize rather than supplant the neoliberal paradigm. It would however signify the end of the Third Way 'variant' of neoliberalism, as British government debt increased in just three years from 43.7 percent in 2007 to 78.4 percent in 2010 . The focus of economic policy switched from combining efficiency with social justice through a growing and enabling state, to reducing the fiscal deficit and restoring confidence in markets through measures of austerity and a shrinking state apparatus. This shift would come into focus during the general election campaign in the spring of 2010, when the Tories' persuasive power over the economic narrative - 'Gordon Brown's recession,' 'New Labour's irresponsible spending,' 'avoiding a Greek scenario,' and a 'crisis of debt' - took hold of both popular and elite imagination.

\section{Cameron and Osborne's Austere Variant of Neoliberalism (2010-2016)}

The election manifestos of Labour and Conservative parties were noticeably different in 2010. Brown and Labour focused on 'growth' and 'living standards' in the first two chapters of their manifesto under the heading 'rebuilding our economy. ${ }^{\text {vi }}$ While admitting that tough choices needed to be made over the next parliament, Labour was careful to frame the crisis as one of deficient growth. Brown promised not to put the recovery at risk by "reckless cuts to public spending," but instead pledged to more than halve the deficit by 2014 through "economic growth, fair taxes, and cuts to lower priority spending." vii David Cameron's Conservatives started their manifesto with a section on "get the economy moving" with the following words: "Gordon Brown's debt, waste and taxes have wrecked the economy and threaten to kill the recovery."viii The emphasis of the Tory manifesto was on ensuring macroeconomic stability, promising urgent action to reduce the debt if elected and "eliminate the bulk of the structural deficit" over their first term in office. The Tories also proposed to set up an independent Office for Budget Responsibility (OBR) to "restore trust in the government's ability to manage the public finances." "ix In other words, Brown's Labour framed the crisis as one of too little growth while Cameron's Conservatives' crisis narrative was one of too much debt. 
The 2010 election saw the Conservative Party win 36.1 percent of the overall vote (a gain of 3.7 percent compared to 2005) and 306 seats (a gain of 97), while Labour lost 6.2 percent of its 2005 vote share to poll just 29 percent and 258 seats (a loss of 91). A hung parliament was overcome when Cameron formed a coalition government with Nick Clegg's Liberal Democrats, which with 23 percent of the vote only had 57 seats due to Britain's first-past-the-post electoral system. Given the Tories' relative weight in the coalition, they would be able to push through the bulk of their economic ideas. Indeed, as observed by Johnson and Chandler (2015, p. 167), "in the list of contents in the coalition's programme for government there [was] no heading for 'growth' or 'the economy' - just 'deficit reduction."' This captured the direction of economic policymaking for the next five years.

While the BoE continued its ultra loose monetary policy, Osborne set out to shrink the size of the British state, starting with an 'emergency' budget in June 2010, which outlined his plans to consolidate public spending to the tune of 7 percent of GDP, with roughly three quarters coming from spending cuts and one quarter from new revenue, including a hike in VAT (Johnson and Chandler, p. 168-69). While the NHS, schools and foreign aid were largely shielded, unprotected departments saw a cumulative cut of 17 percent over the course of the parliament between 2010 and 2015 (Johnson and Chandler, p. 176). Figure 1 shows how total expenditure as a percentage of GDP fell from 48.8 percent in 2010 to 43 percent by 2015 . The main trouble for Osborne, however, was that his austerity measures put a damper on growth, explaining why total revenue as a percentage of GDP remained stagnant between 39.1 percent in 2010 and 38.8 percent in 2015. This meant that the budget deficit, though reduced dramatically from 9.7 percent of GDP in 2010, remained high at 4.4 percent in 2015 , and was a long way off from being eliminated.

The independent Office of Budget Responsibility (OBR) was duly created immediately after Cameron became Prime Minister, and would quickly become an integral part of the new austerity consensus, as Labour's shadow chancellor Ed Balls "was calling for its powers to be significantly extended to enable it to cost the policies put forward by the major parties in their general election manifestos" (Johnson and Chandler, p. 164). Indeed, by the 2015 general election, Labour's new leader Ed Miliband promised to match the Tories' proposed spending plans for 2015-16. The 2015 Labour manifesto started with a "Budget Responsibility Lock" promising that every new policy would be paid for and not result in additional borrowing. 
With Cameron returning to Downing Street in May 2015, this new and austere variant of neoliberalism would be cemented in the corridors of Whitehall as Osborne continued with his plans for further fiscal consolidation and a new round of spending cuts. However, the shock referendum result of June 2016 in which the British people voted to leave the European Union led to the premature ouster of Cameron and Osborne, and their replacement by Theresa May and Philip Hammond. While May's government showed renewed enthusiasm for industrial policy, the neoliberal paradigm is unlikely to be challenged, though it may well herald the beginning of another, less austere, variant.

\section{Conclusion: Of Paradigms and Power}

Carving out a central role for ideational power has important implications for how we think about policy paradigms and why they can persist for long periods of time. First, bringing ideational power into the equation points us towards the importance of authority. Where Hall (1993) created an analytical split between the Bayesian quasi automatic loss of authority following the onslaught of policy anomalies, and the constructivist sociological contests for authority between incommensurate policy paradigms, a perspective on ideational power instead puts the emphasis squarely on the constructivist battle of ideas, as shown in the evolution of ideas within the neoliberal paradigm in Britain since Thatcher left office in 1990. This aligns with Blyth's (2013, p. 204) point that coalitions of policy actors "may both 'power and puzzle,' but successful ones authoritatively dictate what a puzzle is and how power should be applied to solve it." Our sequential approach to how ideational power plays out tries to answer the question of how actors perceive paradigms and their ability to solve problems, and connects the question to relations of power - during as well as outside periods of crisis - rather than to the rational effects of experience and information updating.

Furthermore, by analytically granting actors the ability to think strategically and outside of the policy paradigm they support, bringing in ideational power opens up the possibility for gradual, but significant, change within policy paradigms. A Kuhnian understanding of paradigms has the effect of disposing the paradigm approach for only acknowledging punctuated equilibriums. But if we open up the possibility that actors are able and willing to significantly adjust or 'mold' a paradigm - for example in the effort to broker between coalitions of actors, or in adjusting it to 
unforeseen consequences - our approach is better able to detect significant gradual ideational change either over long periods of time, or following a crisis. The ideational power of policy actors is important in this context, since it helps account for the cases where actors have had to defend the status quo by acknowledging competing ideas and discourses.

Additionally, the agency-orientation of our understanding of ideational power should be distinguished from the structural theories of theoretical dominance. In this paper, we have emphasized actors' abilities to stand outside and engage critically with the ideas they hold and promote. This follows from the distinction between ideational power at the subjective and inter-subjective level implied by the inclusion of persuasive power through ideas as central for understanding processes of paradigmatic change. In such a perspective, ideas are not thought of as internalized or 'contained' in the minds of actors, but instead as a resource or a weapon - a toolkit and not a coherent system - that exists between and not inside the minds of actors, and the use of ideas thus demands some creativity and critical faculty of the actor.

Finally, we want to emphasize that our sequential approach is by no means the only way to think about intra-paradigm ideational change. That said, we do think our approach could travel to other cases. For example, we think of the gradual ideational change that occurred within the ordoliberal paradigm that governs Europe's single currency, within which EU policy elites felt constrained to function after 2010. After 2012, however, numerous actors in the European Commission and especially in the European Central Bank managed to use their persuasive power through ideas to introduce more fiscal and monetary flexibility into the system, and put those ideas into practice once they had institutional power over those ideas, like Mario Draghi at the ECB and Jean-Claude Juncker at the Commission. Though future research will have to show how well our framework travels.

\section{References}

Bachrach, Peter and Baratz, Morton S. (1962) 'Two Faces of Power', American Political Science Review, 56: 947-52

Baker, Andrew (2015) "Varieties of Economic Crisis, Varieties of Ideational Change: How and why macroeconomic policy and financial regulation differ", New Political Economy 20 (3): 342-366. 
Ban, Cornel (2016), Ruling Ideas. New York: Oxford University Press.

Barnett, Michael and Raymond Duvall (2005) "Power in International Politics", International Organization 59 (4): 39-75.

Baumgartner, F. R. (2013) “Ideas and Policy Change”, Governance, 26(2), 239-58.

Baumgartner, Frank R. and Brian Jones (2009) Agendas and Instability in American Politics (2nd ed.), Chicago: University of Chicago Press.

Béland, D. (2007) "Ideas and institutional change in social security: Conversion, Layering, and Policy Drift," Social Science Quarterly 88 (1): 20-38.

Béland, Daniel and Robert Henry Cox (2016) "Ideas as Coalition Magnets:

Coalition Building, Policy Entrepreneurs, and Power Relations," Journal of European Public Policy 23 (3): 428-445.

Béland, Daniel, Martin B. Carstensen and Leonard Seabrooke (eds.) (2016) "Ideas, Power and Public Policy," Journal of European Public Policy 23 (3): 315-317.

Berman, Sheri (2013) "Ideational Theorizing in the Social Sciences Since 'Policy Paradigms, Social Learning, and the State," Governance 23 (6): 217-237.

Blyth, Mark (2002) Great Transformations. Cambridge: Cambridge University Press.

Blyth, Mark (2013) "Paradigms and Paradox: The Politics of Economic Ideas in Two Moments of Crisis," Governance 26 (2): 197-215.

Boswell, Christina and James Hampshire (2017) "Ideas and agency in immigration policy: A discursive institutionalist approach," European Journal of Political Research 56: 133-150.

Campbell, John L. (1998) "Institutional analysis and the role of ideas in political economy," Theory and Society 27 (3): 377-409.

Carstensen, Martin B. (2011a) "Ideas are not as stable as political scientists want them to be: A theory of incremental ideational change," Political Studies 59 (3): 596-615.

Carstensen, Martin B. (2011b) "Paradigm man vs. the bricoleur: An alternative vision of agency in ideational change," European Political Science Review 3 (1): 147-167.

Carstensen, Martin B. (2013) "Projecting from a Fiction: The Case of Denmark and the Financial Crisis," New Political Economy 18 (4): 555-578.

Carstensen, Martin and Vivien A. Schmidt (2016) "Power through, over and in ideas: Conceptualizing ideational power in discursive institutionalism," Journal of European Public Policy 23 (3): 318-37. 
Clift, Ben and Jim Tomlinson (2007) "Credible Keynesianism? New Labour Macroeconomic Policy and the Political Economy of Coarse Tuning," British Journal of Political Science 37 (1): 47-69.

Culpepper, Pepper (2008) "The Politics of Common Knowledge: Ideas and Institutional Change in Wage Bargaining," International Organization 62 (1): 1-33.

Dahl, Robert A. (1957) “The Concept of Power,” Behavioral Science 2 (3): 201-215.

Gamble, Andrew (2005) "The Meaning of the Third Way," in Anthony Seldon and Dennis Kavanagh (eds.), The Blair Effect 2001-5. Cambridge: Cambridge University Press, pp. 430-438.

Hall, Peter (1993) "Policy Paradigms, Social Learning, and the State: The Case of Economic Policymaking in Britain," Comparative Politics, 25 (3), pp. 275-96.

Hay, Colin (1999) The Political Economy of New Labour. Manchester: Manchester University Press.

Hay, Colin (2011a) "Pathology Without Crisis? The Strange Demise of the AngloLiberal Growth Model," Government and Opposition 46 (1): 1-31.

Hay, Colin (2011b) "Britain and the Global Financial Crisis: The Return of Boom and Bust," in Heffernan, Cowley and Hay (eds.), Developments in British Politics. London: Palgrave Macmillan, pp. 238-256.

Heffernan, Richard (2001) New Labour and Thatcherism. New York: Palgrave.

Jenson, Jane (2010) "Diffusing Ideas for after Neoliberalism", Global Social Policy 10 (1): 59-84.

Johnson, Paul and Daniel Chandler (2015) "The Coalition and the Economy," in Seldon and Finn (eds.), The Coalition Effect 2010-2015, Cambridge: Cambridge University Press, pp. 159-193.

Keegan, William (2004) The Prudence of Mr. Gordon Brown, Chichester: Wiley Publishers.

Kingdon, John W. (2003) Agendas, Alternatives, and Public Policies (2nd ed.), New York, NY: Longman.

Kuhn, T. (1970) The Structure of Scientific Revolutions, $2^{\text {nd }}$ edition, Chicago: University of Chicago Press.

Lukes, Steven (1974) Power: A Radical View, London: MacMillan

Matthijs, Matthias (2011) Ideas and Economic Crises in Britain from Attlee to Blair, New York: Routledge. 
Matthijs, Matthias (2016) "Powerful Rules Governing the Euro: The Perverse Logic of German Ideas," Journal of European Public Policy 23 (3): 375-391.

Matthijs, Matthias and Kathleen McNamara (2015) "The Euro Crisis' Theory Effect: Northern Saints, Southern Sinners, and the Demise of the Eurobond," Journal of European Integration 37 (2): 229-245.

Oliver, Michael J. and Hugh Pemberton (2004) "Learning and Change in 20thCentury British Economic Policy," Governance 17 (3): 415-441.

Parsons, Craig (2007) How to Map Arguments in Political Science, Oxford: Oxford University Press

Schmidt, Vivien. A. (2002) The Futures of European Capitalism, Oxford: Oxford University Press.

Schmidt, Vivien A. (2008) "Discursive Institutionalism: The Explanatory Power of Ideas and Discourse," Annual Review of Political Science, 11: 303-26

Schmidt, Vivien A. and Mark Thatcher (eds.) (2013) Resilient Liberalism in Europe's Political Economy, Cambridge: Cambridge University Press.

Seldon, Anthony (2005) "The Second Blair Government: The Verdict," in Anthony Seldon and Dennis Kavanagh (eds.), The Blair Effect 2001-5 (Cambridge: Cambridge University Press), pp. 410-429.

Widmaier, Wesley W., Mark Blyth and Leonard Seabrooke (2007) "Exogenous Shocks or Endogenous Constructions? The Meanings of Wars and Crises," International Studies Quarterly 51 (4): 747-759.

Wilder, Matt (2015) "Ideas beyond paradigms: relative commensurability and the case of Canadian trade-industrial policy, 1975-1995," Journal of European Public Policy, 22 (7): 1004-1021.

Wilder, Matt and Michael Howlett (2014) "The Politics of Policy Anomalies: Bricolage and the Hermeneutics of Paradigms," Critical Policy Studies 8 (2): 183202.

Wood, Matthew (2015) "Puzzling and Powering in Policy Paradigm Shifts: Politicization, Depoliticization and Social Learning," Critical Policy Studies 9 (1): 221.

\footnotetext{
i The authors wish to thank Eddie Ashbee, Daniel Beland, John L. Campbell, Ben Clift, Peter A. Hall, John Hogan, Craig Parsons, Vivien A. Schmidt, Kathryn Sikkink and two anonymous reviewers for very helpful comments and suggestions that have greatly benefitted the paper. The paper was
} 
presented at the American Political Science Association Annual Meeting, September 1-4, 2016, Philadelphia. Comments received in that setting are gratefully acknowledged. Usual disclaimer applies. ii Note that there are limits to how much public expenditure and revenue (as a \% of GDP) can reveal about ideas and policies. Obviously, there were automatic stabilizers that kicked in during the recessions of 1990-92 and 2008-9. Nonetheless, the broad pattern of UK fiscal policy should be clear from figure 4.

iii Labour Party (1997), "New Labour because Britain Deserves Better.” Available at: http://www.politicsresources.net/area/uk/man/lab97.htm

iv The main changes came in social and employment policies, including the introduction of a minimum wage and the (symbolically important) signing up to the EU's social chapter.

v Conservative Party (2005), “Are You Thinking What We're Thinking? It's Time for Action" Available at: http://news.bbc.co.uk/2/shared/bsp/hi/pdfs/11_04_05_conservative_manifesto.pdf

vi Labour Party (2010), “A Future Fair for All.” Available at: http://www.cpa.org.uk/cpa_documents/TheLabourPartyManifesto-2010.pdf

vii Ibid., p. 1:2.

viii Conservative Party (2010), "Invitation to join the government of Britain." Available at: https://www.conservatives.com/ /media/Files/Manifesto2010

ix Ibid., p. 7. 